\title{
Sarcoidosis simulating metastasis in patient with Merkel cell carcinoma
}

\author{
Sarcoidose simulando metástase em paciente com carcinoma de células de Merkel
}

Nathália Bordeira Chagas ; ; Lucimar Retto da Silva de Avó²; Victor Hugo Maion³; Michel Antonio Kiyota Moutinho4;

Débora Gusmão Melo5; Carla Maria Ramos Germano6

\begin{abstract}
Merkel cell carcinoma (MCC) is a rare and aggressive skin neuroendocrine tumor whose etiology remains little known. The immune system dysfunction is considered one of the possible causes, shared with other diseases, like sarcoidosis. This article presents the case of a male patient, in the seventh decade of life, which had a prior MCC diagnosis and was subsequently diagnosed with sarcoidosis, which radiologically simulated lung and mediastinum metastasis. The association between MCC and sarcoidosis is infrequent and rarely described in literature, found in only two case reports.
\end{abstract}

Key words: Merkel cell carcinoma; sarcoidosis; immune system.

\section{INTRODUCTION}

Merkel cell carcinoma (MCC) is a rare and highly aggressive skin cancer. Considered a neuroendocrine tumor derived from mechanoreceptor cells located in the basal layer of the epidermis, it mainly affects areas chronically exposed to the $\operatorname{sun}^{(4)}$.

The annual incidence rates of diagnosed MCC cases are 0.23 and 0.01 per 100 thousand individuals, in Caucasians and Afrodescendants, respectively. It occurs predominantly in older people, with mean age of 69 years at diagnosis, affecting more men (61\%) than women $(39 \%)^{(4)}$. Besides age, other risk factors are associated to its little known etiology: exposure to ultraviolet radiation, Merkel cell polyomavirus infection, and immunosuppression ${ }^{(4,5)}$.

In the literature, immune system dysfunction is pointed as an important factor that may contribute to the occurrence of $\mathrm{MCC}^{(5)}$ and, in a less evident manner, sarcoidosis ${ }^{(2)}-$ a systemic noninfectious granulomatous disease of uncertain etiology ${ }^{(9)}$.

This paper describes the case of a MCC patient who, during the investigation of metastatic disease, presented radiologic imaging suggestive of pulmonary and mediastinal metastasis. Through the histological study, the possibility of metastasis was excluded, and the diagnosis of sarcoidosis was achieved. The association between MCC and sarcoidosis is not common, and it is rarely described in the literature (only two case reports).

\section{CASE REPORT}

The patient was a 70-year old white male, engineer, retired professor, and non-smoker. At the beginning of his career, he worked as an engineer at a metallurgy company for a month and, later, at a car factory for three years. He had noticed a nodule in the gluteal region two years before, which displayed faster growth nine months ago. The patient had a dermatologist check the lesion, and was referred to a general surgeon to excise it.

The pathology report described a lesion with reddish irregular plain surface, measuring $0.5 \times 0.5 \mathrm{~cm}, 0.3 \mathrm{~cm}$ apart from the nearest surgical resection margin. Microscopic examination revealed no epidermal alterations. In the deep dermis and

First submission on 25/10/13; last submission on 13/02/14; accepted for publication on 17/07/14; published on 20/10/14

1. Graduating student of Medicine at Universidade Federal de São Carlos (UFSCar).

2. Pathologist; assistant professor at the Medicine Department of UFSCar.

3. Oncological surgeon.

4. Pathologist.

5. Clinical geneticist; assistant professor at the Medicine Department of UFSCar.

6. Pediatric endocrinologist; assistant professor at the Medicine Department of UFSCar. 
hypodermis, a multinodular malignant neoplasm was identified, formed by small cell-blocks, of scant cytoplasm, round nuclei with uniformly distributed dense chromatin and inconspicuous nucleoli. Mitotic figures and apoptotic corpuscles were frequently observed. Lateral and deep surgical margins coincided with the neoplasm (Figure 1).

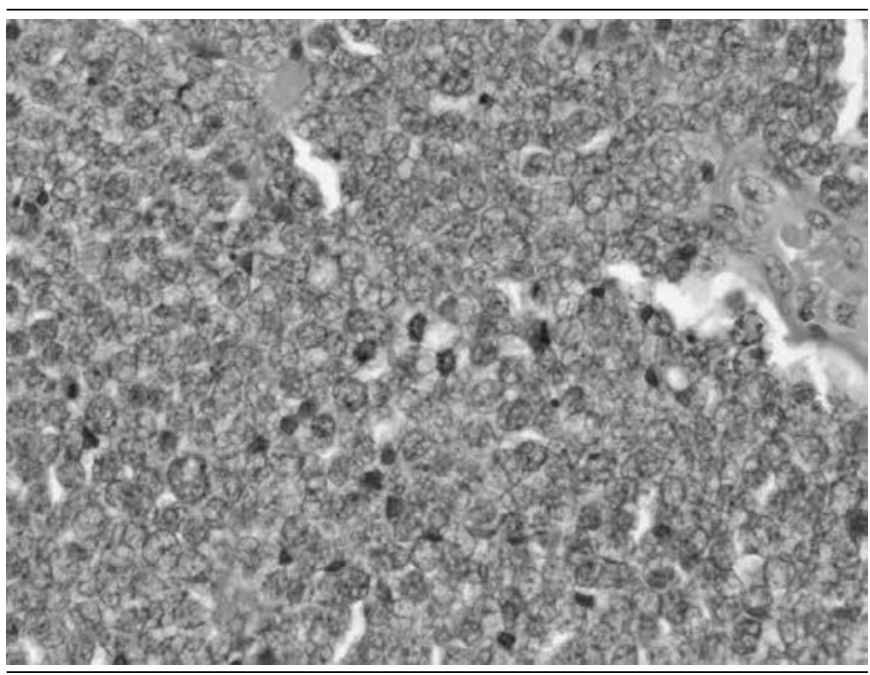

FIGURE 1 - Photomicrograph of MCC, formed by cells with round homogeneous nuclei, scant cytoplasm, and numerous mitotic figures. HE, 400x

MCC: Merkel cell carcinoma; HE: hematoxylin and eosin.

Immunohistochemical staining was positive for cytokeratin 20, chromogranin A, Ki67 and synaptophysin; and negative for thyroid transcription factor (TTF-1)/lung, CD20 and CD3, confirming the diagnosis of MCC (Figure 2).

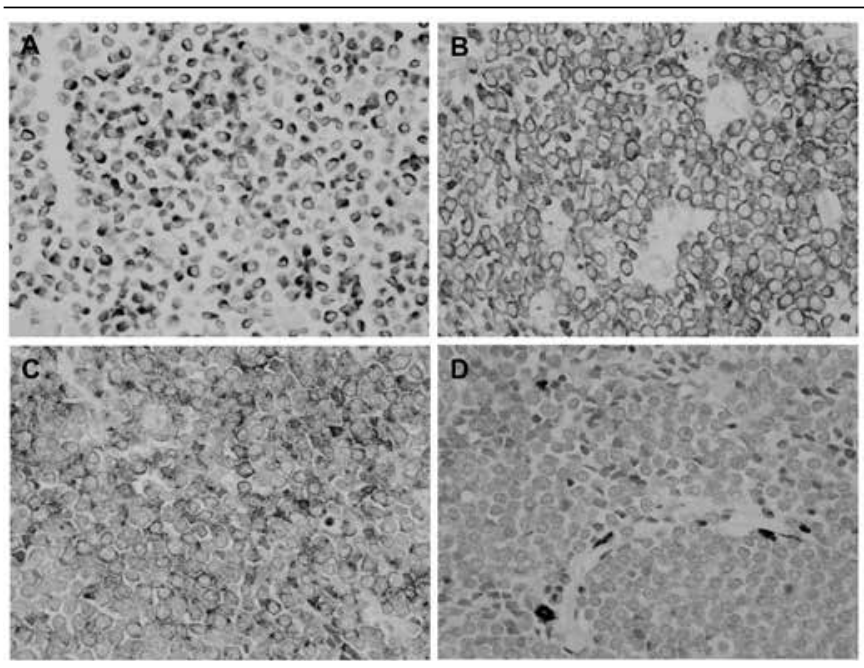

FIGURE 2 -Immunohistochemical staining of biomarkers used in the diagnosis of MCC: A) positive for cytokeratin 20 (clone KS20.8); B) positive for synaptophysin (clone SY38); C) positive for chromogranin A (clone DAK-A3); D) negative for T-cell receptor-CD3 (epsilon chain) (polyclonal)

MCC: Merkel cell carcinoma.
After diagnosis, the patient was referred to an oncologic surgeon to widen the margins. At clinical assessment, he did not present any respiratory symptom, as well as fever, weight loss, fatigue or night sweats. His physical examination was described as normal. At the previously operated site, there was a newly-formed scar with no signs of relapse. The widening of surgical margins was performed, and a thoracic computed tomography (CT) with contrast enhancement was required for staging. The CT revealed mediastinal adenomegaly, multiple pulmonary nodules and micronodules, suggestive of metastatic neoplasia (Figure 3).

Based on these findings, sentinel lymph node biopsy, right inguinal lymph node dissection and segmental left lung resection through videothoracoscopy were proposed. The histological examination of surgical specimens showed granulomatous inflammation, in the different analyzed tissues, besides a chronic nonspecific inflammatory process in the scar and in tissue from the widened surgical margins (Figure 4). The investigations of alcohol-acid-resistant bacilli (AARB) (using Ziehl-Neelsen staining) and fungi (using methenamine silver staining) were negative, both at lymph nodes and pulmonary segment, reinforcing the diagnostic hypothesis of sarcoidosis.

After the diagnosis of sarcoidosis, the patient was examined by a pneumologist, who performed a pulmonary function test. This exam revealed a mild chronic obstructive process, and the regular use of an inhaled glucocorticoid was prescribed. The patient is currently on regular oncologic follow-up, with no evidence of active neoplastic disease.

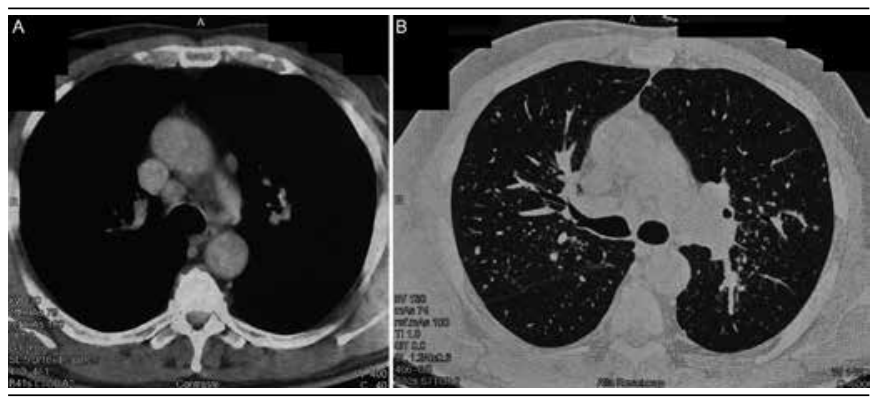

FIGURE 3 - Thoracic computed tomography showing mediastinal adenomegaly, multiple pulmonary nodules and micronodules

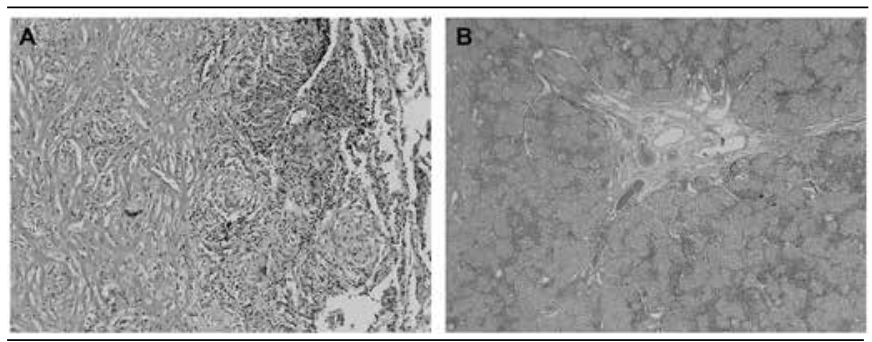

FIGURE 4 - Photomicrograph showing multiple noncaseating granulomas, suggestive of sarcoidosis: A) lung; B) lymph node 


\section{DISCUSSION}

MCC typically presents as a rapid growing (weeks or months) painless violaceous nodule. It usually arises on sunexposed regions, like the head and neck (41\%-50\%), followed by the extremities (32\%-38\%) and the trunk $(12 \%-14 \%)^{(1,4)}$. Occurrence in the gluteal region, as observed in this patient, is uncommon, with few cases described in the literature.

Diagnosis is established by biopsy, and to differentiate MCC from other tumors, immunohistochemistry is performed ${ }^{(5)}$. This study highlights positivity for cytokeratin 20 (whose expression is detected in $89 \%-100 \%$ of MCC) ${ }^{(10)}$ and negativity for TTF-1 (which is specific for small cell lung carcinoma) ${ }^{(6)}$ as important tools for the differential diagnosis of MCC.

Due to the aggressive behavior of this cancer, besides exeresis of the primary tumor, the sentinel lymph node biopsy has been adopted. It serves as a complementary diagnostic strategy for detecting metastasis ${ }^{(5)}$, since lymph node involvement at diagnosis is considered an important prognostic factor ${ }^{(11)}$, being present in 50\%-70\% of MCC patients. In the present case, sentinel lymph node biopsy revealed the presence of noncaseating epithelioid granulomas, with negative results for $A A R B$ and fungi. Histological examination of the resected lung segment presented the same aspect, reinforcing the diagnostic hypothesis of sarcoidosis.

Sarcoidosis is a systemic inflammatory non-infectious disease in which noncaseating epithelioid granulomas are the microscopic elementary lesions. The lung and the lymphatic system are the predominantly affected sites ${ }^{(9)}$. The prevailing etiological hypothesis, still not definite, is that multiple nonidentified antigens, both infectious and environmental, can trigger an exaggerated immune reaction in genetically susceptible hosts. Its incidence is slightly higher in women (1.3\%) than in men (1\%), and higher in Blacks (2.4\%) than in Caucasians $(0.8 \%)$. It is generally sporadic, although a positive family history is found in $17 \%$ of the cases ${ }^{(9)}$.

The disease spectrum is wide, and the clinical presentation may comprise asymptomatic patients, whose sarcoidosis is incidentally discovered through an abnormal chest radiograph (8\%-60\% of the cases), a situation compatible with our patient's. Likewise there are symptomatic patients, whose manifestations may be: a) respiratory, like persistent dry cough (30\%); b) extrathoracic, principally affecting peripheral lymph nodes, eyes and skin; c) erythema nodosum (3\%-44\%); or finally, d) unspecific constitutional symptoms such as fatigue (27\%), weight loss (28\%), fever (10\%-17\%) and night sweats ${ }^{(9)}$.

The case reported in this paper generates two discussions: the value of histological examination in the differential diagnosis of metastatic disease suggested by imaging, and the association between sarcoidosis and MCC.

Differentiation between sarcoidosis and metastasis is probably not a simple process. Fluorodeoxyglucose positronemission tomography (FDG-PET), widely used in the assessment of neoplastic diseases, is quite effective to differentiate malignant from inflammatory lesions ${ }^{(6)}$. Kaira et al. $(2007)^{(7)}$ report that the use of PET with $\mathrm{L}\left[3^{-}{ }^{18} \mathrm{~F}\right]$-alpha-methyltyrosine $\left({ }^{18} \mathrm{~F}\right.$-FMT-PET) in combination with FDG-PET may distinguish sarcoidosis from malignancy, and may be a useful tool in this differential diagnosis. It is worth emphasizing that these exams are of difficult access far from large diagnostic centers, and they were not available for use in the cited case.

In a literature review, we found one case, published in 2005, in which the association between sarcoidosis and MCC was described in an 84-year-old female with chronic sarcoidosis who had MCC diagnosed on her face nine years later ${ }^{(8)}$.

A more recent case, described in 2011, reports a 57-yearold woman with MCC diagnosed in the left inguinal region, with an associated granulomatous reaction suggestive of mediastinal lymph node sarcoidosis ${ }^{(6)}$. Other similar studies were not found in the medical literature, what attests that the association between both diseases is rare and may represent just a coincidence.

The pathogenesis of sarcoidosis, as well as that of MCC, although poorly understood, seems to involve immune dysfunction, what may represent a causal factor for the coexistence of these diseases in a patient ${ }^{(8)}$. Cohen and Kurzrock $(2007)^{(3)}$, in a literature review, state that sarcoidosis may develop in association with different neoplasms. A possible explanation lies in the administration of antineoplastic drugs that could both lead to the occurrence and activate a focus of latent sarcoidosis. This does not apply to the present case, since the patient did not undergo chemotherapy.

The coexistence of sarcoidosis and MCC may hamper the detection of metastasis and the adequate grading of the neoplasia. Thus, physicians need to pay close attention to this possibility. The fact that sarcoidosis may simulate metastases in imaging analysis reinforces the importance of histological examination in the differential diagnosis of these cases. 


\section{RESUMO}

O carcinoma de células de Merkel (CCM) é um tumor neuroendócrino de pele, raro e agressivo, cuja etiologia permanece pouco compreendida. Disfunção do sistema imune é apontada como um possivel fator causal, tanto para o CCM quanto para a sarcoidose. Este artigo descreve o caso de um paciente do sexo masculino, na sétima década de vida, com diagnóstico de CCM, posteriormente diagnosticado com sarcoidose, que, à radiologia, simulava metástase para pulmão e mediastino. A associação entre CCM e sarcoidose é rara e muito pouco descrita na literatura, encontrada em apenas dois relatos de casos.

Unitermos: carcinoma de célula Merkel; sarcoidose; sistema imune.

\section{REFERENCES}

1. ALMEIDA, M. W. R. et al. Carcinoma de células de Merkel em extremidade inferior. Rev Col Bras Cir, v. 39, n. 2, p. 165-7, 2012.

2. BZHALAVA, D. et al. Risk of second cancers after the diagnosis of Merkel cell carcinoma in Scandinavia. Br J Cancer, v. 104, n. 1, p. 178-80, 2011. 3. COHEN, P. R.; KURZROCK, R. Sarcoidosis and malignancy. Clin Dermatol, v. 25, n. 3, p. 326-33, 2007.

4. DUPRAT, J. P. et al. A review of the epidemiology and treatment of Merkel cell carcinoma. Clinics, v. 66, n. 10, p. 1817-23, 2011.

5. GOMES, C. A. et al. A importância da linfocintilografia no tratamento do carcinoma de células Merkel. Rev Col Bras Cir, v. 38, n. 5, p. 361-5, 2011.
6. HIGASHI, Y.et al.Sarcoid reaction associated with Merkel cell carcinoma revealed by fluorodeoxyglucose positron emission tomography: a case report.J Med Case Rep, v. 5, n. 282, 2011.

7. KAIRA, K. et al. Diagnostic usefulness of fluorine-18-alfa-methyltyrosine positron emission tomography in combination with ${ }^{18} \mathrm{~F}$-fluorodeoxyglucose in sarcoidosis patients. Chest, v. 131, n. 4, p. 1019-27, 2007.

8. McLOONE, N. M. et al. Merkel cell carcinoma in a patient with chronic sarcoidosis. Clin Exp Dermatol, v. 30, n. 5, p. 580-2, 2005.

9. NUNES, H. et al. Sarcoidosis. Orphanet J Rare Dis, v. 2, n. 46, 2007.

10. PERMAN, M. J. et al. Giant Merkel cell carcinoma masquerading as a benign cyst on the buttock of an African American man. Case Rep Oncol Med, v. 2011; 2011: 849767.

11. POULSEN, M. Merkel-cell carcinoma of the skin. Lancet Oncol, v. 5 , n. 10, p. 593-9, 2004. 